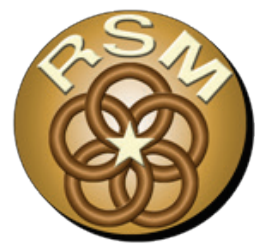

\title{
Contribution of Two Eroding Banks to Multipurpose Pool Sedimentation at a Midwestern Reservoir
}

\author{
by John Shelley, Mackenzie Kenney, Anthony Layzell, and Tracy Brown
}

PURPOSE: This US Army Corps of Engineers (USACE) National Regional Sediment Management Technical Note (RSM-TN) documents the sediment contribution of two eroding banks to multipurpose pool sedimentation at Kanopolis Lake, KS. The analysis is based on a 2009 LIDAR and an August 2019 unmanned aircraft systems (UAS)-based structure from motion survey.

INTRODUCTION: Reservoir sedimentation is a growing problem at USACE lakes around the country. Quantifying sediment sources is an important step towards finding solutions, as in some cases prevention is less expensive than remediation. Sediment source studies have typically focused on quantifying the preponderance of fluvial vs. overland sediments (Juracek and Ziegler 2009) or in locating erosional hotspots in the watershed (Juracek 1999). Erosion of the reservoir banks themselves, however, has been recognized but only quantified at a handful of reservoirs. In a study of 10 reservoirs, Gato and Doe (1987) find bank erosion rates that range from $0.6 \mathrm{~m} /$ year to $11.9 \mathrm{~m} /$ year. Siquiera et al. (2015) note erosion rates between 0.1 and $1 \mathrm{~m} /$ year at the Porto Primavera Dam reservoir in Brazil. Neither study quantified the volume of sediment contributed by the bank erosion.

Kanopolis Lake is a multi-purpose USACE reservoir in north-central Kansas that suffers both chronic and acute problems due to sedimentation. The dam was built in 1948 and had an assumed multipurpose pool sedimentation rate of $451 \mathrm{ac}-\mathrm{ft} /$ year $\left(727,600 \mathrm{yd}^{3} / \mathrm{year}\right)^{* \dagger}$. The original estimate was remarkably accurate - from 1948 to 2007, 24,822 ac-ft of sediment accumulated in the multipurpose pool, which equates to $421 \mathrm{ac}-\mathrm{ft} / \mathrm{year}\left(678,748 \mathrm{yd}^{3} / \mathrm{year}\right.$ ) (KWO 2012). While not unexpected, the sediment deposition still represents a major problem, as the multipurpose pool was (as of 2007) 57\% full of sediment and multiple counties depend on Kanopolis Lake for their water supply. In addition, Kanopolis provides discharges to the Kansas River which, along with other Kansas River Basin reservoirs, impact major cities such as Topeka, Lawrence, and Kansas City (Figure 1). A pool raise was deemed untenable due to the hydrologic deficiency of the spillway.

\footnotetext{
${ }^{*}$ For a full list of the spelled-out forms of the units of measure used in this document, please refer to US Government Publishing Office Style Manual, 31st ed. (Washington, DC: US Government Publishing Office 2016), 248-52, https://www.govinfo.gov/content/pkg/GPO-STYLEMANUAL-2016/pdf/GPO-STYLEMANUAL-2016.pdf.

${ }^{\dagger}$ For a full list of the unit conversions used in this document, please refer to US Government Publishing Office Style Manual, 31st ed. (Washington, DC: US Government Publishing Office 2016), 345-7, https://www.govinfo.gov/content/pkg/GPO-STYLEMANUAL-2016/pdf/GPO-STYLEMANUAL-2016.pdf.
} 


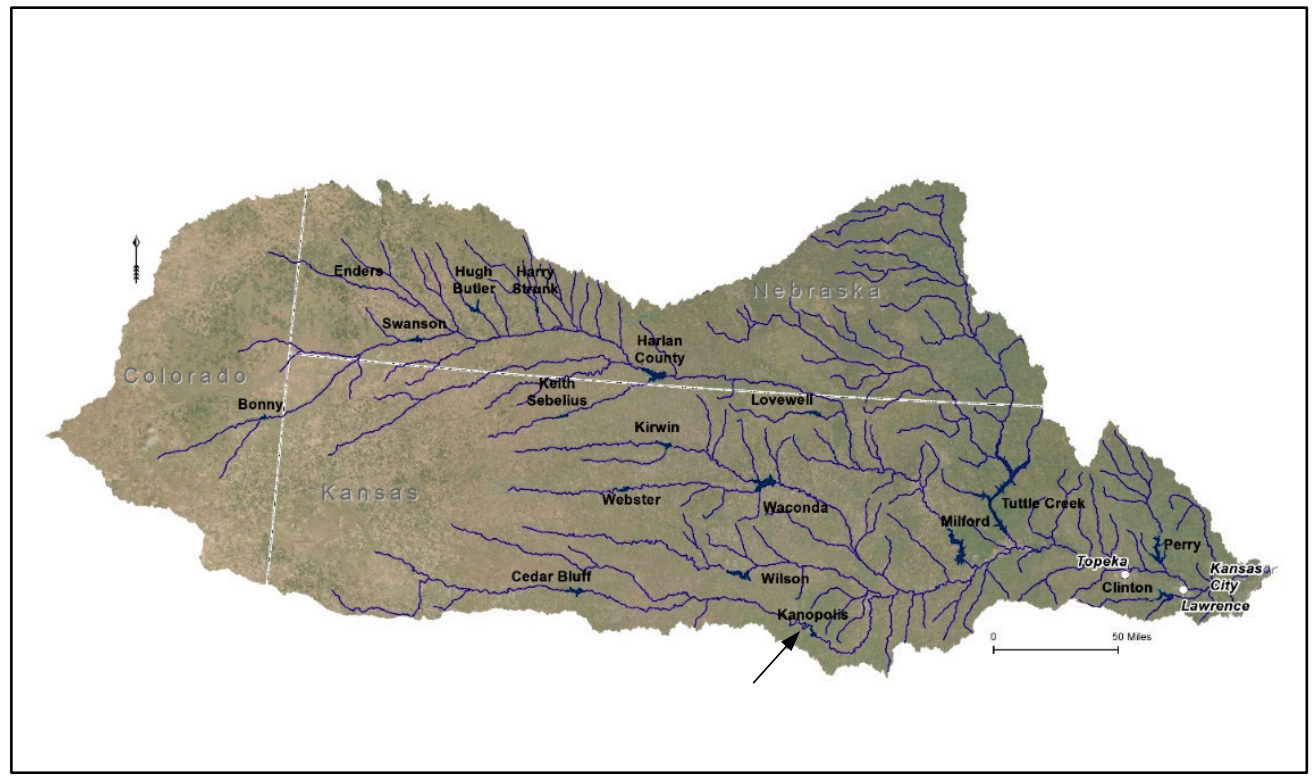

Figure 1. Kanopolis Lake in the Kansas River basin.

In addition to chronic problems caused by diminishing storage, sediment accumulation has caused expensive problems with gate operations at Kanopolis Lake. In 2010, so much sediment had accumulated in the control tower's conduit and approach channel that the emergency gate could not be fully deployed within the gate slots. The Kansas City District undertook a $\$ 1.1 \mathrm{M}$ dredging project to clear out $5,000 \mathrm{yd}^{3}$ of sediment from near the control tower. A second dredging project was undertaken in 2019 at a cost of approximately $\$ 2.5 \mathrm{M}$ to clear sediment that had again deposited (Figure 2). The first dredging project occurred after 62 years. The second was needed after only seven additional years. A tall bank to the left of the tower has visibly eroded in recent years and is thought to be the source of the sediment that accumulates in the approach channel (Figure 3).

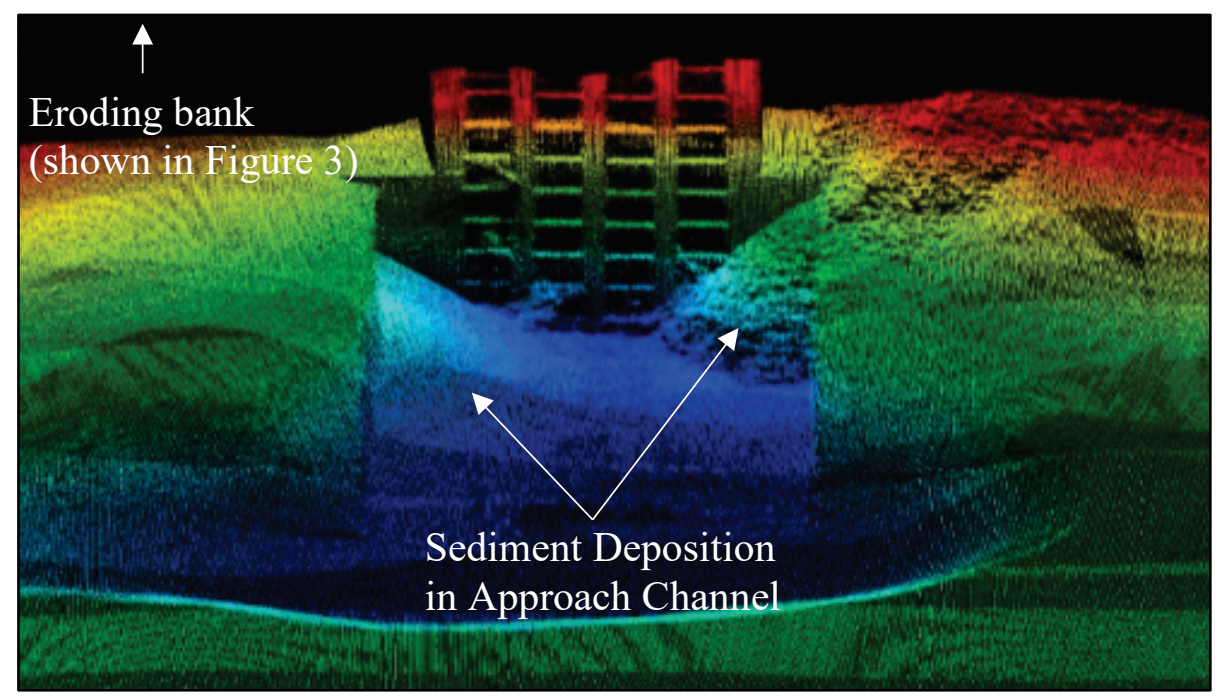

Figure 2. Multibeam survey of Kanopolis Lake indicating deposited sediments in the approach channel. 


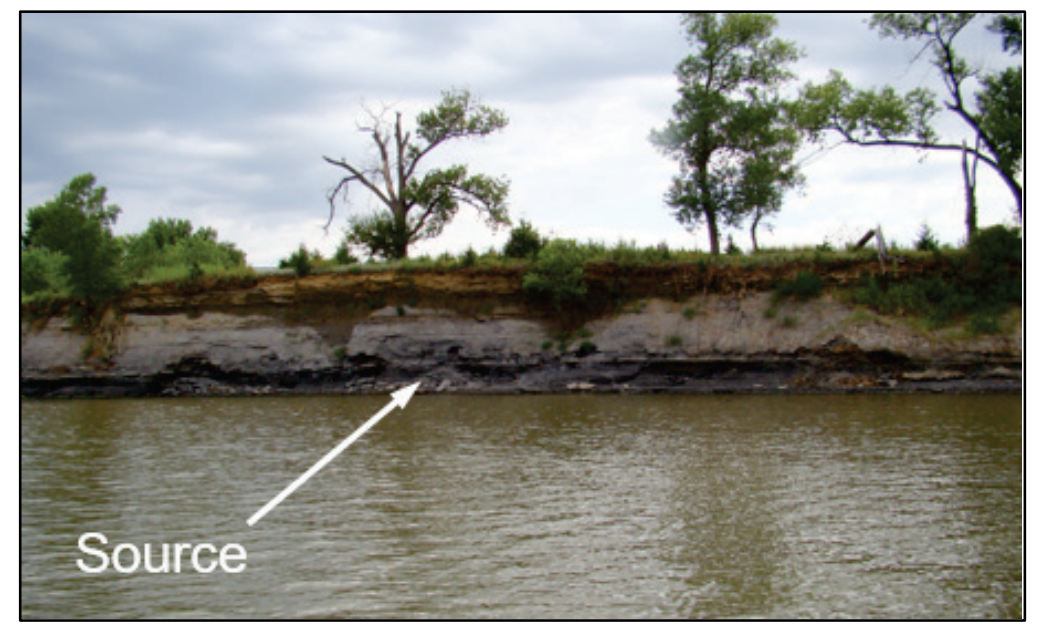

Figure 3. Eroding bank near the control tower.

Eroding banks are prevalent at Kanopolis Lake. When these banks fail, large quantities of sediment residing in the flood control pool collapse into the multipurpose pool. The volumetric contribution of eroding banks to multipurpose pool sedimentation has never been quantified.

This RSM-TN documents the procedure and provides the results of a surface analysis to compute the volume of bank erosion from two eroding banks, as shown in Figure 4. Bank 1 is immediately behind the control tower, including the eroding bank shown in Figure 3. Bank 2 is nearby to the right at the toe of Kanopolis State Park. A subsequent report will document the cumulative contribution of all the banks.

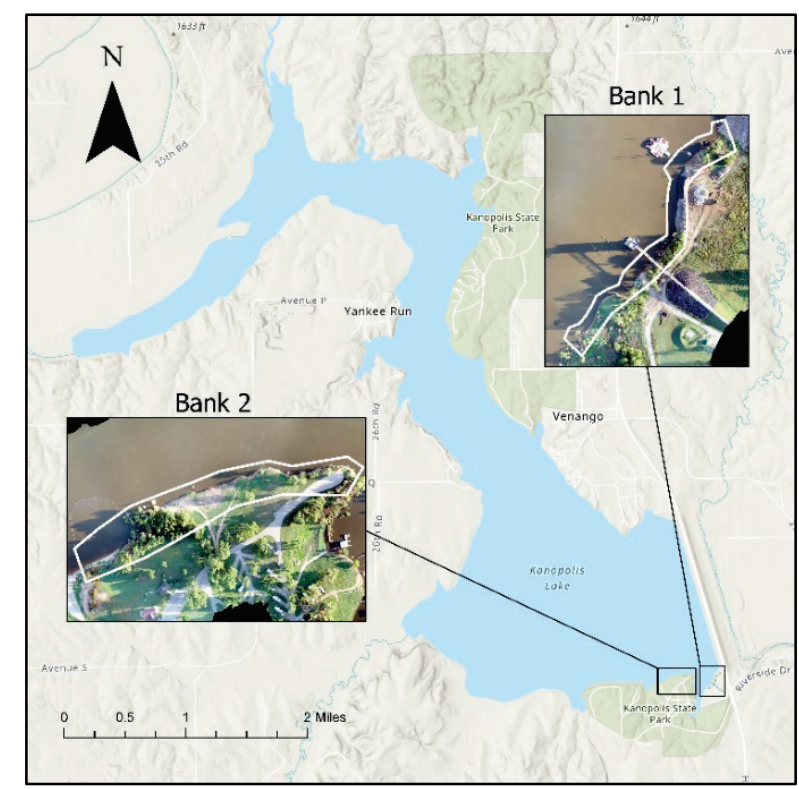

Figure 4. Eroding banks analyzed in this RSM-TN.

DATA AND PROCEDURES: The volumetric computation was accomplished by differencing two surfaces generated from a 2009 LIDAR and a 2019 structure-from-motion (SfM) survey. The 2009 LIDAR data set, depicted in Figure 5, was captured at a $2 \mathrm{~m}$ cell density with a hydroflattened water surface of $1469.7 \mathrm{ft}$. 


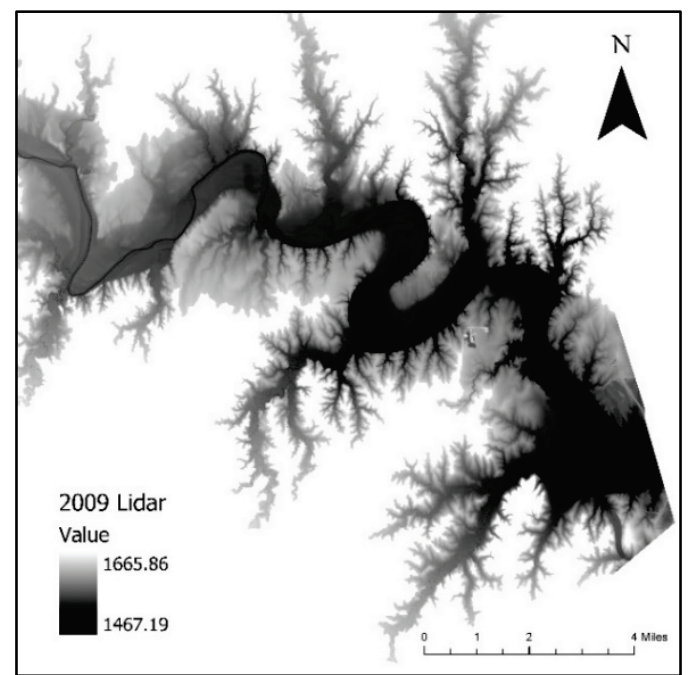

Figure 5. Digital Elevation Model (DEM) surface from 2009 LIDAR.

The 2019 SfM survey was conducted by the Kansas Geological Survey from 23 August 2019 to 28 August 2019 using a remotely operated UAS* (Shelley 2019.) Over the course of the survey, significant inflows caused the pool to fluctuate from $1469.6 \mathrm{ft}$ to $1476.4 \mathrm{ft}$. The data were adjusted to established ground points set around the lake. The SfM survey yielded a DEM with $6 \mathrm{~cm}$ cell size. The 2019 data set was resampled to the same $2 \mathrm{~m}$ cell density as the 2009 data to allow comparisons (Figure 6).

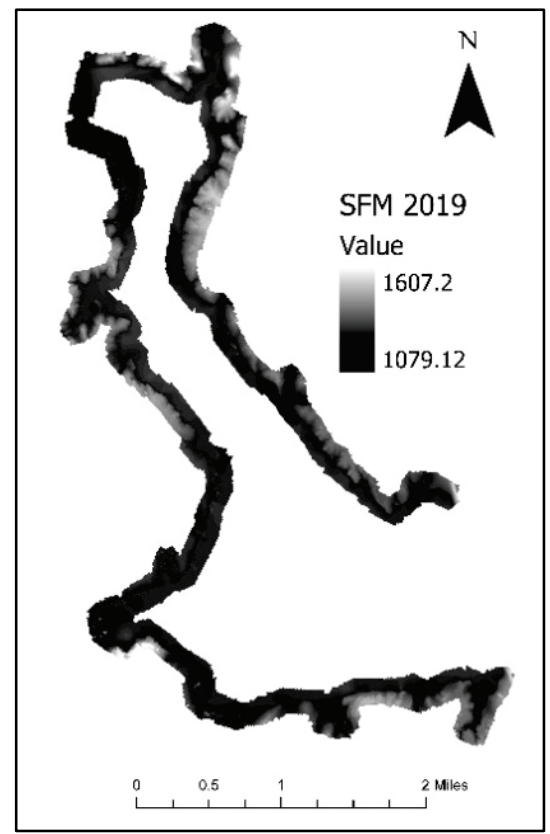

Figure 6. DEM surface from 2019 structure from motion.

${ }^{*}$ A copy of this report can be obtained from the Kansas Geological Survey. 
The process for bank erosion evaluation was completed in ArcGIS Pro as follows:

1. Two shapefiles were created to enclose the area of interest.

2. Each DEM raster was clipped to only encompass the desired polygons created in the previous step.

3. The minimum elevations in the 2009 LIDAR and the 2019 SfM raster were set equal to the water surface of the 2019 raster. This prevents erroneous volume from being computed between the water surface in one survey and the bank in another. As SfM poorly resolves water, GIS* was utilized to identify a sufficiently high water surface elevation that exceeds the variability in the reported water surface near the bank. This value was $1478.6 \mathrm{ft}$ for both subject banks.

4. The adjusted surveys were subtracted.

5. The DEM of difference from the previous step was processed to eliminate any values less than 0 . This eliminated any apparent deposition on the bank. By inspection, values less than 0 on the bank appeared to be primarily numerical artifacts induced by the differing cell densities of the underlying data, by errors in the SfM survey's bare earth computation, and erroneous deposition on the top of bank caused by vertical inaccuracies in the surveys. For example, even with bare earth processing, the SfM survey would detect higher elevations from a tree that was not detected by the 2009 survey. Even if included, negative erosion volumes were very small and would have only a minimal impact on the total.

6. The Zonal Statics Tool was utilized to sum the depth change raster. This sum was multiplied by the cell size to create a total volume change. This is valid because

$$
\Delta V=\sum \Delta d_{i} A_{\text {cell }}=A_{\text {cell }} \sum \Delta d_{i}
$$

where $\Delta \mathrm{d}_{\mathrm{i}}$ equals the change in depth in cell $i$,

$$
\begin{aligned}
& A_{\text {cell }}=\text { the surface area of a cell } \\
& \Delta \mathrm{V}=\text { the total volume of bank erosion. }
\end{aligned}
$$

The resulting measured volume change does not represent the total eroded volume; it represents the volume eroded from the bank above the water surface elevation of the 2019 survey. The pool elevation varied over the course of the 2019 SfM survey but was $1478.6 \mathrm{ft}$ at the two subject banks, which is $15.6 \mathrm{ft}$ above the multipurpose pool elevation of $1463 \mathrm{ft}$. Thus, a significant amount of the eroded bank was underwater during the SfM survey and therefore was not included in the change analysis. However, this area can be estimated by assuming the rate of erosion per vertical foot is the same above the water surface as below, which is true if the 2009 and 2019 bank slopes remain parallel to each other down to the multipurpose pool level. This un-counted volume was estimated by multiplying the unit volume of bank erosion per vertical foot by $15.6 \mathrm{ft}$, the distance between the water surface and the multipurpose pool. The unit volume was computed as the eroded volume in the first $3 \mathrm{ft}$ vertical slice above the SfM pool level (from 1478.6 to $1481.6 \mathrm{ft}$ ) divided by 3 . Figure 7 illustrates this concept in cross section view at Bank 2. As seen in Figure 7, at Bank 2 the high pool on the day of the 2019 survey necessitates estimating most of the erosion.

\footnotetext{
* Geographic Information System
} 


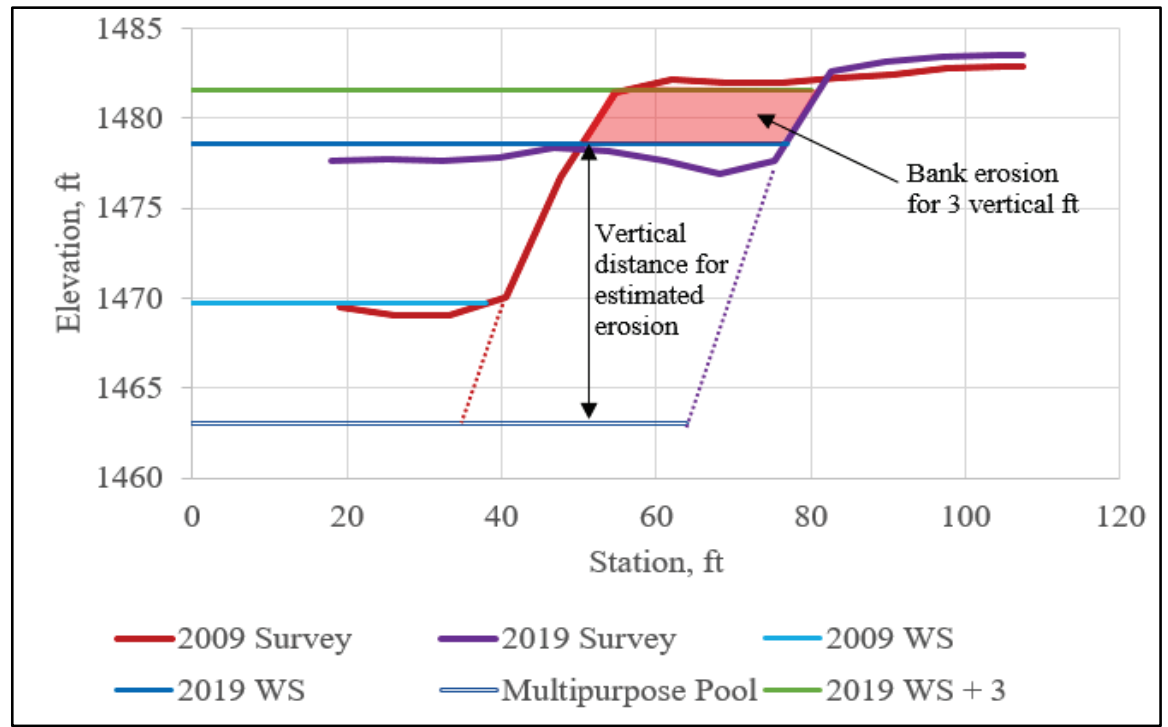

Figure 7. Conceptual illustration for estimating the unmeasured area at Bank 2.

RESULTS AND DISCUSSION: Table 1 provides the results of the analysis.

\begin{tabular}{|c|c|c|c|c|}
\hline Bank & $\begin{array}{c}\text { Measured } \\
\text { Erosion } \\
\left(\mathrm{yd}^{3}\right)\end{array}$ & $\begin{array}{c}\text { Estimated } \\
\text { Erosion } \\
\left(\mathrm{yd}^{3}\right)\end{array}$ & $\begin{array}{c}\text { Total Erosion } \\
\qquad\left(\mathrm{yd}^{3}\right)\end{array}$ & $\begin{array}{c}\% \\
\text { Estimated }\end{array}$ \\
\hline Bank 1 & 4,350 & 1,785 & 6,135 & $29 \%$ \\
\hline Bank 2 & 2,483 & 9,349 & 11,832 & $79 \%$ \\
\hline
\end{tabular}

The combined contribution from these two eroding banks is $17,968 \mathrm{yd}^{3}$ from 2009 to 2019 , or an average annual contribution of $1,797 \mathrm{yd}^{3} /$ year. This equates to $0.26 \%$ of the 1946 to 2007 annual average accumulation of $678,748 \mathrm{yd}^{3} /$ year. At this time, the number of erosion sites on Kanopolis has not been quantified. However, the small percentage for these two banks suggests that reservoir bank erosion has been a minor contributor to multipurpose pool sedimentation at Kanopolis Lake.

Next steps include the following:

1. Re-fly the UAS survey after the pool has dropped to the multi-purpose pool elevation so more of the erosion can be measured instead of estimated.

2. Repeat the analysis for the remaining banks at Kanopolis.

3. Repeat the analysis using two LIDAR data sets (LIDAR was flown in late 2018, but it has not yet been processed and made available) and compare to the rates generated using the SfM survey.

4. Compare the contribution of bank erosion to a more recent annual estimate for reservoir sedimentation. Other reservoirs in the watershed have indicated that the current rates of reservoir sedimentation may be much less than the long-term rates. Thus, recent bank erosion may be a larger percentage of recent sedimentation. 
This RSM-TN documented how a UAS-based SfM survey can be used to assess reservoir bank erosion. The analysis suggested that while reservoir bank erosion at Kanopolis Lake has caused acute sedimentation impacts, it contributed only a minor portion of the total sediment accumulation in the multi-purpose pool. Due to the high water surface and limited number of banks assessed, more analysis is needed to definitively determine the relative contribution of reservoir bank erosion vs. other sediment sources.

ADDITIONAL INFORMATION: The analysis presented in this RSM-TN was funded by the USACE National RSM program, a Navigation Research, Development, and Technology Transfer portfolio program administered by Headquarters, USACE. For information on the RSM program, please consult http://rsm.usace.army.mil or contact the USACE National RSM Program Manager, Dr. Katherine E. Brutsché, Katherine.E.Brutsche@erdc.dren.mil. For information regarding this RSM-TN, please contact John Shelley, John.Shelley@usace.army.mil. The 2019 UAS survey was conducted by the Kansas Geological Survey and funded by the Kansas Water Office through the USACE Planning Assistance to States program.

This RSM-TN should be cited as follows:

Shelley, J., M. Kenney, A. Layzell, and T. Brown. 2020. Contribution of Two Eroding Banks to Multipurpose Pool Sedimentation at a Midwestern Reservoir. ERDC/TN RSM-20-6. Vicksburg, MS: US Army Engineer Research and Development Center. http://dx.doi.org/10.21079/11681/37946

\section{REFERENCES}

Gatto, L.W., and W. W. Doe. 1987. "Bank Conditions and Erosion along Selected Reservoirs." Environmental Geology and Water Sciences 9(3): 143-154. https://doi.org/10.1007/BF02449947

Juracek, K. E. 1999. Estimation of Potential Runoff-Contributing Areas in the Kansas-Lower Republican River Basin, Kansas. US Geological Survey Water-Resources Investigations Report 99-4089. https://doi.org/10.3133/wri994089

Juracek, K., and A. Ziegler. 2009. "Estimation of Sediment Sources Using Selected Chemical Tracers in the Perry Lake Basin, Kansas, USA." International Journal of Sediment Research 24(1).

KWO (Kansas Water Office). 2012. Kanopolis Lake Reservoir Fact Sheet. Topeka, KS: Kansas Water Office. https://kwo.ks.gov/reservoirs

Shelley, J. 2019. Kanopolis Lake Bank Erosion Drone Video. Collected by Alan Peterson and Tony Layzell, Kansas Geological Survey, August 2019. https://www.youtube.com/watch?v=9Pq1B_RH0qI

Siqueira A. G., A. A. Azevedo, L. F. S. Dozzi, and H. Duarte. 2015. "Monitoring Program of Reservoir Bank Erosion at Porto Primavera Dam, Parana River, SP/MS, Brazil." Engineering Geology for Society and Territory. Vol. 3. Switzerland: Springer.

NOTE: The contents of this technical note are not to be used for advertising, publication, or promotional purposes. Citation of trade names does not constitute an official endorsement or approval of the use of such products. 